\title{
ANALISIS KESALAHAN MENYELESAIKAN SOAL- SOAL PECAHAN BERDASARKAN TAKSONOMI BLOOM DAN KEMAMPUAN AWAL SISWA KELAS V SD NEGERI RAPPOCINI
}

\author{
Rasid Ode, Kasriana \\ Program Studi Pendidikan Matematika, \\ Program Pascasarjana Universitas Negeri Makassar \\ rasidode@unidar.ac.id
}

\begin{abstract}
Abstrak
Penelitian ini bertujuan untuk mendeskripsikan kesalahan menyelesaikan soal-soal pecahan berdasarkan toksonomi bloom dan kemampuan awal siswa. Tujuan penelitian ini adalah (i) mendeskripsikan kesalahan konseptual dan prosedural dalam menyelesaikan soal-soal pecahan; Dan (ii) mendeskripsikan penyebab terjadinya kesalahan konseptual dan prosedural dalam menyelesaikan soal-soal pecahan. Hasil penelitian ini menunjukkan bahwa (i) kesalahan konseptual terjadi pada subjek berkemampuan tinggi dan sedang yaitu salah menggunakan, memanfaatkan, dan memilih prosedur atau operasi tertentu, salah mengaitkan berbagai konsep, salah mengklasifikasi objekobjek menurut sifat-sifat tertentu sesuai dengan konsepnya, dan salah menyatakan ulang sebuah konsep. Kesalahan prosedural yang terjadi pada subjek berkemampuan tinggi dan sedang yaitu salah menggunakan langkahlangkah dalam menyelesaikan soal-soal pecahan, salah memanipulasi langkah-langkah untuk menjawab suatu soal, melakukan penyimpulan tanpa alasan yang benar, serta salah dalam mencermati dan memahami petunjuk tes diagnostik (ii) penyebab terjadinya kesalahan yang dilakukan siswa antara lain adalah siswa kurang teliti membaca dan memahami maksud dari soal sehingga melakukaan kesalahan dalam menuliskan apa yang diketahui dan apa yang ditanyakan, siswa kurang memahami materi pecahan sehingga kurang mampu dalam menyelesaikan soal yang berkaitan dengan materi tersebut, daya ingat siswa terhadap rumus maupun pengertian-pengertian mengenai materi pecahan masih kurang sehingga siswa mengalami kesalahan dalam menyelesaikan soal-soal.
\end{abstract}

Kata kunci: Analisis kesalahan, taksonomi bloom, kemampuan awal

\begin{abstract}
Concept in mathematics learning is the basic element that must be understood by students. The objectives of the research are to describe (i) conceptual and procedural mistakes in solving fractions questions; and (ii) the cause of conceptual and procedural mistakes in solving fractions questions. The results of the research showed that (i) conceptual mistakes occurred to high and medium ability subjects, namely mistake in connecting various concepts, mistake in classifying certain objects according to certain characters based on the concept, and mistake in restating a concept. Procedural mistakes occurred to high and medium ability subjects, namely mistake in using stages in solving fractions questions, mistake in manipulating stages in
\end{abstract}


solving fractions questions, mistake in manipulating stages to answer a question, drawing conclusion without the right reason, and mistake in observing and understanding diagnostic test instructions, namely students did not continue solving stage; (ii) the causes of the mistakes which were conducted by the students were: students did not read carefully and lack of comprehension of the questions so they conducted mistake in writing what had been understood and being questioned, students had lacked of understanding the meaning of what was asked in the question so they conducted mistake in writing the final answer according to what was stated in the question, the students had lacked of understanding in fraction material so they were less' able in understanding on fractions material were low so they had mistakes in solving the questions.

Keywords: Analysis of mistakes, bloom's taxonomy, students initial abilities.

Sitasi: Ode, R., Kasriana. 2018. Analisis Kesalahan Menyelesaikan Soal- Soal Pecahan Berdasarkan Taksonomi Bloom dan Kemampuan Awal Siswa Kelas V SD Negeri Rappocini. Matematika dan Pembelajaran, 6(2), 172-183.

\section{PENDAHULUAN}

Matematika merupakan salah satu bagian yang penting dalam bidang ilmu pengetahuan. Apabila dilihat dari sudut pengklasifikasikan bidang ilmu pengatahun, pelajaran matematika termasuk ke dalam kelompok ilmu- ilmu ekstra, yang lebih banyak memerlukan pemahaman dari pada hafalan. Seorang yang dikemukakan oleh seorang arsitek dengan nama samara Le Corbuser yang nama aslinya ialah Charles Edouard Jeanneeret (1889-1965): mengemukakan mathematics is the majestic structure conceived by man to grant comprehension of the universe"'matematika adalah struktur besar yang dibangun oleh manusia untuk memberikan pemahaman mengenai jagat raya'”. (Muhibbinsyah 2010).

Matematika sering dideskripsikan dengan cara yang berbeda-beda tergantung dari sudut pandang mana yang dipakai. Menurut Sumardyono (2004: 28), beberapa deskripsi matematika yang sering dipergunakan adalah sebagai berikut:

1. Matematika sebagai struktur yang terorganisir, berbeda dengan ilmu dan pengetahuan yang lain, matematika merupakan suatu bangunan struktur yang terorganisir. Sebagai sebuah struktur, ia terdiri dari beberapa komponen diantaranya meliputi aksioma/postulat, pengertian, pangkal/primitive, dandalil/teorema.

1. Matematika sebagai alat, matematika sering juga dipandang sebagai alat dalam mencari solusi berbagai masalah kehidupan sehari-hari. 
2. Matematika sebagaipola pikir deduktif, matematika merupakan pengetahuan yang berpola pikir deduktif, artinya suatu teori atau pernyataan dalam matematika diterima kebenarannya bila telah dibuktikan secara deduktif (umum)

3. Matematika sebagai cara bernalar, matematika dapat pula dipandang sebagai cara bernalar, paling tidak karena beberapa hal, seperti matematika memuat cara pembuktian yang sahih (valid), rumus-rumus atau aturan yang umum, atau sifat penalaran matematika yang sistematis.

4. Matematika sebagai bahan artifisial, simbol merupakan ciri yang paling menonjol dalam matematika. Bahasa matematika adalah bahasa simbol yang bersifat artifisial, yang baru memiliki arti bila dikenakan pada suatu konteks.

5. Matematika sebagai seni yang kreatif, penalaran yang logis dan efisien serta perbendaharaan ide-ide dan pola-pola yang kreatif dan menakjubkan, maka matematika sering pula disebut sebagai seni, khususnya merupakan seni berfikir yang kreatif.

Menurut Akib (2016) matematika dijiwai oleh perjanjian yang memberikan batas-batas dalam mengurangi apapun pernyataan maupun operasi. Hal ini berati bahwa perjajian yang terkait dengan nilai kesetiaan.

Sedangkan menurut Soedjadi beberapa definisi atau pengertian tentang matematika yaitu:

1. Matematika adalah cabang ilmu pengetahuan eksak dan terorganisir secara sistematis.

2. Matematika adalah pengetahuan tentang bilangan dan kalkulasi

3. Matematika adalah pengetahuan tentang penalaran logic dan berhubungan dengan bilangan.

4. Matematika adalah pengetahuan tentang fakta-fakta kuantitatif dan masalah tentang ruang dan bentuk.

5. Matematika adalah pengetahuan tentang struktur-struktur yang logic.

6. Matematika adalah pengetahuan tentang aturan-aturan ketat.

Fakta saat ini siswa lebih banyak berpeluang untuk melakukan kesalahan pada operasi pecahan jika pembelajaran materi pecahan hanya menitikberatkan pada menghafal rumus dan prosedur operasi tanpa ada perhatian yang cukup pada makna pecahan. Kesalahan yang sering dilakukan siswa dalam menyelesaikan soal-soal matematika berdasarkan kawasan kognitif yang diidentifikasi mencakup tiga aspek yaitu: aspek pengetahuan/ingatan, aspek pemahaman, dan aspek penerapan/aplikasi Soedjadi (dalam Noraida Ariyunita,2010). Ranah kognitif pada taksonomi bloom dibedakan 
menjadi enam tingkatan dengan aspek belajar yang berbeda-beda, yaitu meliputi mengingat, memahami, mengaplikasikan, menganalisis, mengevaluasi dan mencipta. Berdasarkan hasil observasi, bahwa dari sekian banyak hasil penelitian tentang tasonomi bloom sudah terlalu umum yang menggunakan $\mathrm{C} 1$ mengingat, C2 memahami, C3 mengaplikasikan, sehingga saya sebagai peneliti sendiri merasa tertarik dengan menggunakan C4 menganalisis, C5 mengevaluasi, C6 mencipta untuk melihat sejauh mana pemahaman siswa dalam menyelesaikan soal-soal dengan menggunakan tiga ranah kognitif. Adapun tiga ranah kognif dalam penelitian ini sebagai berikut; (Anderson lorin:2015)

\section{Menganalisis $\mathrm{C} 4$}

Menganalisis melibatkan proses memecah-mecahkan materi jadi bagian-bagian kecil dan menentukan bagaimana hubungan antara bagian dan antara setiap bagian dan struktur keseluruhannya.

2. Mengevaluasi $\mathrm{C} 5$

Mengevaluasi didefenisikan sebagai membuat keputusan berdasarkan kriteria dan standar.

\section{Mencipta C6}

Mencipta melibatkan proses menyusun elemen-elemen jadi sebuah keseluruhan yang koheren atau fungsional

Pengetahuan konseptual merupakan pengetahuan tentang kategori, klasifikasi, dan hubungan antara dua atau lebih kategori atau klasifikasi pengetahuan yang lebih komplesk dan tarterah.

Adapun indikator kesalahan menurut peraturan dirjen depdiknas nomor 506/c/kep/pp/2004(harja) dalam sumarniati 2012 adalah berdasarkan indikator konseptual adalah sebaga berikut:

a. Salah menyatakan ulang sebuah konsep adalah siswa salah mengungkap kembali apa yang telah dikomunikasikan kepadanya.

b. Salah mengklasifikasikan objek-objek menurut sifat-sifat tertentu (sesuai dengan konsepnya) adalah kesalahan siswa mengelompokan suatu objek menurut jenisnya berdasarkan sifat-sifat yang terdapat dalam materi

c. Salah menyajikan konsep dalam berbagai bentuk adalah kesalahan siswa untuk memaparkan konsep secara berurutan yang bersifat matematis. 
d. Salah menggunakan, memanfaatkan, dan memilih prosedur atau operasi tertentu adalah kesalahan siswa dalam menyelesaikan soal yang tidak sesuai dengan prosedur yang tepat.

e. Salah mengaitkan berbagai konsep adalah kesalahn siswa dalam menggunakan konsep serta prosedur dalam menyelesaikan soal yang berkaitan dengan kehidupan seharihari.

Pengetahuan prosedural adalah pengetahuan tentang cara melakukan sesuatu."' Melakukan sesuatu" ini boleh mengerjakan latihan rutin sampai menyelesaikan masalahmaslah baru.

Adapun indikator kesalahan menurut peraturan dirjen depdiknas nomor 506/c/kep/pp/2004(harja) dalam sumarniati 2012 adalah Salah menggunakan langkahlangkah dalam menyelesaikan soal adalah kesalahan siswa dalam menuliskan dan memilih prosedur matematika yang telah di berikan sebelumnya.

a. Salah memanipulasi langkah-langkah untuk menjawab suatu soal. adalah kesalahan siswa dalam memilih langkah-langkah untuk menyelesaikan suatu masalah dalam matematika.

b. Salah melakukan penyimpulan tanpa alasan yang benar adalah kesalahan siswa dalam menarik kesimpulan dari suatu soal tanpa memberikan alasan yang benar.

\section{METODE PENELITIAN}

Jenis penelitian ini deskriptif kualitatif, yakni menggambarkan suatu kejadian, kemudian melihat hasil kerja siswa yang terjadi dalam objek penelitian yaitu analisis kesalahan menyelesaikan soal-soal pecahan berdasarkan taksonomi bloom dan kemampuan awal siswa Penelitian ini dilaksanakan di SD Negeri Rappocini. Peneliti memilih subjek dilihat dari kemampuan awal siswa. Calon subjek penelitian adalah siswa kelas V SD Negeri Rappocini. Banyak subjek dalam penelitian ini adalah 4 orang siswa kelas V SD Negeri Rappocini yang terdiri 2 (dua) siswa berkemampuan tinggi dan 2 (dua) siswa berkemampuan sedang. Tes kemampuan matematika adalah tes awal yang diberikan kepada seluruh siswa kelas V SD Negeri Rappocini untuk memilih subjek penelitian. Tes kemampuan matematika tersebut terdiri dari 5 butir soal pecahan. Soal-soal pecahan yang diberikan pada materi kelas V SD yang digunakan untuk mengungkap kesalahan siswa kelas V SD Negeri Rappocini dalam analisis menyelesaikan soal- soal pecahan berdasarkan kemampuan awal siswa sesuai indikator. 
Uji kredibilitas data dilakukan dengan observasi lebih tekun, yaitu peneliti mewawancarai subjek dengan teliti dan rinci secara berkesinambungan. Peneliti mengatakan tringulasi untuk memvalidkan data. Tringulasi adalah tringulasi metode, yaitu memadukan dua metode yakni metode tes dan wawancara guna melihat sifat konsistensi data yang diperoleh. Pengujian transferabilitas dilakukan dengan cara menyusun laporan hasil penelitian secara rinci, jelas, sistematis, dan dapat dipercaya serta menguraikan secara rinci level berpikir siswa menurut van hiele berdasarkan gaya kognitif, meliputi (1) pemelihan subjek penelitian yang sesuai teori dan tujuan penelitian (2) pengembangan instrumen pendukung yang valid secara konstruksi dan isi (3) pengumpulan data sesuai teori, (4) mencari keabsahan data sesuai dengan teori (5) melakukan analisis data serta melaporkan hasil penelitian secara sistimatis. Dependabelitas dilakukan dengan melakukan audit terhadap keseluruhan proses penelitian. Comfirmability berarti menguji hasil penelitian, dikaitkan dengan proses yang dilakukan. Adapun teknik analisis data adalah sebagai berikut.

1) Reduksi data, reduksi data adalah pemilihan dan penyederhanaan data. kegiatan ini dilakukan untuk menghindari penumpukan data atau informasi yang dari siswa.

2) Penyajian data, data yang disajikan berupa jenis- jenis kesalahan yang dilakukan siswa dalam menyelesaikan soal- soal pecahan. Membuat Coding yang bertujuan untuk memudahkan pemaparan data dalam menyelesaikan soal-soal pecahan, maka dilakukan coding pada petikan jawaban subjek penelitian saat wawancara.

Dalam penelitian ini, kode yang digunakan ditunjukkan pada Tabel 3.3

Tabel 3.3 Makna Kode Data

Kode Makna Kode

$\mathrm{ST}_{1} \mathrm{~S}_{1} / 01 \quad$ Subjek berkemampuan tinggi ke-1 menjawab soal nomor 2 dan pertanyaan ke-1

\begin{tabular}{cl}
\hline $\mathrm{ST}_{2} \mathrm{~S}_{1} / 01$ & $\begin{array}{l}\text { Subjek berkemampuan tinggi ke-2 menjawab soal nomor 1 dan } \\
\text { pertanyaan ke-1 }\end{array}$ \\
\hline $\mathrm{SS}_{1} \mathrm{~S}_{1} / 01$ & $\begin{array}{l}\text { Subjek berkemampuan sedang ke-1 menjawab soal nomor 1 dan } \\
\text { pertanyaan ke-1 }\end{array}$ \\
\hline $\mathrm{SS}_{2} \mathrm{~S}_{1} / 01$ & $\begin{array}{l}\text { Subjek berkemampuan sedang ke-2 menjawab soal nomor 1 dan } \\
\text { pertanyaan ke-1 }\end{array}$ \\
\hline 3) Verifikasi dan menarik kesimpulan, verifikasi data dan penarikan kesimpulan sebelum
\end{tabular}
kegiatan analisis berlangsung sehingga diperoleh suatu analisis terhadap data yang telah dikumpulkan baik melalui tes, maupun melalui wawancara dengan siswa: 


\section{HASIL DAN PEMBAHASAN}

1. Analisis kesalahan siswa berkemampuan tinggi dalam menyelesaikan soal-soal pecahan pada tahap menganalisis $(\mathrm{C} 4)$

Hasil penelitian menunjukan bahwa subjek berkemampuan tinggi menggunakan kemampuan analisis pada kata kerja membedakan dalam menyelesaikan soal, dimana subjek berkemampuan tinggi (ST) mampu mengidentifikasi elemen-elemen yang relevan atau yang penting dalam soal.Pada kata kerja mengorganisasi subjek berkemampuan tinggi (ST) mampu menentukan struktur yang terbentuk dari elemen-elemen tersebut. Sedangkan pada kata kerja mengatribusi subjek berkemampuan tinggi (ST) tidak mampu menentukan tujuan dari soal yang diberikan. Jadi pada ketiga kata kerja yang tardapat dalam tahap menganalisis, subjek berkemampuan tinggi (ST) mampu menyelesaikan sebanyak $60 \%$.

2. Analisis kesalahan siswa berkemampuan tinggi dalam menyelesaikan soal-soal pecahan pada tahap mengevaluasi (C5)

Hasil penelitian menunjukan bahwa subjek berkemampuan tinggi menggunakan kemampuan mengevaluasi pada kata kerja memeriksa dalam menyelesaikan soal. Sedangkan pada kata kerja mengkritik subjek berkemampuan tinggi (ST) tidak memahami soal. Jadi pada kedua kata kerja yang terdapat dalam tahap mengevaluasi, subjek berkemampuan tinggi (ST) cenderung tidak mampu menyelesaikan soal yang diberikan.

3. Analisis kesalahan siswa berkemampuan tinggi dalam menyelesaikan soal-soal pecahan pada tahap mencipta (C6)

Hasil penelitian menunjukan bahwa pada kata kerja merumuskan, subjek berkemampuan tinggi (ST) tidak memahami soal sehingga subjek sulit membuat hipotesi-hipotesis berdasarkan kriteria tertentu. Pada kata kerja merencanakan subjek berkemampuan tinggi (ST) sulit merencanakan prosedur untuk memecahkan masalah. Sedangkan pada kata kerja memproduksi subjek berkemampuan tinggi (ST) sulit dalam mencipta suatu produk Jadi pada ketiga kata kerja yang tardapat dalam tahap mencipta, subjek berkemampuan tinggi (ST) cenderung tidak mampu menyelesaikan soal yang diberikan. 


\section{Analisis kesalahan siswa berkemampuan sedang dalam menyelesaikan soal-soal} pecahan pada tahap menganalisis $(\mathrm{C} 4)$

Hasil penelitian menunjukan bahwa subjek berkemampuan sedang (SS) kurang menggunakan kemampuan analisis pada kata kerja membedakan dalam menyelesaikan soal, dimana subjek berkemampuan sedang (SS) tidak mengidentifikasi elemen-elemen yang relevan atau yang penting dalam soal Pada kata kerja mengorganisasi subjek berkemampuan sedang (SS) mampu menentukan struktur yang terbentuk dari elemen-elemen tersebut yaitu subjek berkemampuan sedang (SS) dapat menentukan hubungan-hubungan dari soal, Sedangkan pada kata kerja mengatribusi subjek berkemampuan sedang (SS) tidak mampu menentukan tujuan dari soal yang diberikan. Jadi pada ketiga kata kerja yang tardapat dalam tahap menganalisis, subjek berkemampuan sedang (SS) mampu menyelesaikan sebanyak $30 \%$.

5. Analisis kesalahan siswa berkemampuan sedang dalam menyelesaikan soal-soal pecahan pada tahap mengevaluasi (C5)

Hasil penelitian menunjukan bahwa subjek berkemampuan tinggi menggunakan kemampuan mengevaluasi pada kata kerja memeriksa dalam menyelesaikan soal, di mana subjek berkemampuan sedang (SS) tidak mampu menguji apakah suatu kesimpulan sesuai dengan premis-preminya, atau apakah premis-premis berisikan bagian-bagian yang saling bertentangan. Sedangkan pada kata kerja mengkritik subjek berkemampuan sedang (SS) tidak memahami soal, Jadi pada kedua kata kerja yang tardapat dalam tahap mengevaluasi, subjek berkemampuan sedang (SS) cenderung tidak mampu menyelesaikan soal yang diberikan.

6. Analisis kesalahan siswa berkemampuan sedang dalam menyelesaikan soal-soal pecahan pada tahap mencipta (C6)

Hasil penelitian menunjukan bahwa pada kata kerja merumuskan, subjek berkemampuan sedang (SS) tidak memahami soal sehingga subjek sulit membuat hipotesi-hipotesis berdasarkan kriteria tertentu. Pada kata kerja merencanakan subjek berkemampuan sedang (SS) sulit merencanakan prosedur untuk memecahkan masalah. Sedangkan pada kata kerja memproduksi subjek berkemampuan sedang (SS) sulit dalam mencipta suatu produk Jadi pada ketiga kata kerja yang tardapat 
dalam tahap mencipta, subjek berkemampuan sedang (SS) cenderung tidak mampu menyelesaikan soal yang diberikan dengan baik.

\section{KESIMPULAN DAN SARAN}

\section{Kesalahan-kesalahan yang dilakukan siswa dalam menyelesaikan soal-soal pecahan berdasarkan Taksonomi Bloom adalah:}

a. Kesalahan yang dilakukan siswa berkemampuan awal tinggi dalam menyelesaikan soal-soal pecahan berdasarkan taksonomi bloom pada tahap menganalisis.

1) Kesalahan prosedural, hal ini berada pada indikator pertama yaitu salah menentukan langkah-langkah dalam menyelesaikan soal.

2) Kesalahan konseptual, hal ini berada pada indikator kelima yaitu salah menggunakan, memanfaatkan dan memilih prosedur atau operasi tertentu.

3) Kesalahan konseptual, hal ini berdasarkan pada indikator kedua yaitu salah mengklasifikasikan objek-objek menurut sifat-sifat tertentu sesuai dengan konsepnya.

b. Kesalahan yang dilakukan siswa berkemampuan awal tinggi dalam menyelesaikan soal-soal pecahan berdasarkan taksonomi bloom pada tahap mengevaluasi.

1) Kesalahan konseptual, hal ini berada pada indikator keenam yaitu salah mengaitakan berbagai konsep.

2) Kesalahan prosedural, hal ini berada pada indikator kedua yaitu salah memanipulasi langkah-langkah untuk menjawab suatu soal.

c. Kesalahan yang dilakukan siswa berkemampuan awal tinggi dalam menyelesaikan soal-soal pecahan berdasarkan taksonomi bloom pada tahap mencipta.

1) Kesalahan konseptual, hal ini berada pada indikator kedua yaitu salah mengklasifikasikan objek-objek menurut sifat-sifat tertentu sesuai dengan konsepnya.

2) Kesalahan konseptual, hal ini berada pada indikator kelima yaitu salah menggunakan, memanfaatkan dan memilih prosedur atau operasi tertentu.

3) Kesalahan prosedural, hal ini berada pada indikator kedua yaitu salah memanipulasi langkah-langkah untuk menjawab suatu soal.

d. Kesalahan yang dilakukan siswa berkemampuan awal sedang dalam menyelesaikan soal-soal pecahan berdasarkan taksonomi bloom pada tahap menganalisis.

1) Kesalahan prosedural, hal ini berdasarkan pada indikator pertama yaitu salah menggunakan langkah-langkah dalam menyelesaikan soal. 
2) Kesalahan konseptual, hal ini berada pada indikator kelima yaitu salah menggunakan, memanfaatkan dan memilih prosedur atau operasi tertentu.

3) Kesalahan prosedural, hal ini berdasarkan pada indikator ketiga yaitu melakukan penyimpulan tanpa alasan yang benar.

e. Kesalahan yang dilakukan siswa berkemampuan awal sedang dalam menyelesaikan soal-soal pecahan berdasarkan taksonomi bloom pada tahap mengevaluasi.

1) Kesalahan prosedural, hal ini berada pada indikator kedua yaitu salah memanipulasi langkah-langkah untuk menjawab suatu soal.

2) Kesalahan konseptual, hal ini berdasarkan pada indikator keenam yaitu salah mengaitakan berbagai konsep.

f. Kesalahan yang dilakukan siswa berkemampuan awal sedang dalam menyelesaikan soal-soal pecahan berdasarkan taksonomi bloom pada tahap mencipta.

1) Kesalahan konseptual, hal ini berada pada indikator pertama yaitu salah dalam menyatakan ulang sebuah konsep.

2) Kesalahan konseptual, hal ini berada pada indikator kelima yaitu salah menggunakan, memanfaatkan, dan memilih prosedur atau operasi tertentu.

3) Kesalahan prosedural, hal ini berdasarkan pada indikator keempat yaitu kesalahan siswa dalam mencermati dan memahami petunjuk tes diagnostik yaitu siswa tidak melanjutkan langkah-langkah penyelesaian.

2. Penyebab terjadinya kesalahan yang dilakukan siswa dalam menyelesaikan soalsoal pecahan berdasarkan taksonomi bloom adalah:

a. Penyebab terjadinya kesalahan yang dilakukan siswa berkemampuan awal tinggi dalam menyelesaikan soal-soal pecahan berdasarkan taksonomi bloom pada tahap menganalisis.

1) Siswa kurang teliti dan kurang konsentrasi dalam menyelesaikan soal.

2) Siswa tidak memahami apa yang ditanyakan dalam soal.

b. Penyebab terjadinya kesalahan yang dilakukan siswa berkemampuan awal tinggi dalam menyelesaikan soal-soal pecahan berdasarkan taksonomi bloom pada tahap mengevaluasi.

1) Siswa tidak bisa mengaitkan beberapa konsep bilangan yang berbeda.

2) Siswa bingung dan tidak tahu cara penyelesaia pada soal.

3) Siswa tidak mengetahui rumus untuk mencari persentase. 
c. Penyebab terjadinya kesalahan yang dilakukan siswa berkemampuan awal tinggi dalam menyelesaikan soal-soal pecahan berdasarkan taksonomi bloom pada tahap mencipta.

1) Siswa tidak memahami konsep pecahan campuran dan pecahan biasa.

2) Siswa tidak teliti dalam menggunakan tanda operasi pada pecahan.

d. Penyebab terjadinya kesalahan yang dilakukan siswa berkemampuan awal sedang dalam menyelesaikan soal-soal pecahan berdasarkan taksonomi bloom pada tahap menganalisis.

1) Siswa lupa dalam menuliskan apa yang diketahui dalam soal.

2) Siswa keliru dalam menggunakan tanda perbandingan.

3) Siswa salah dalam menarik kesimpulan karena terlalu terburu-buru dan tidak teliti.

e. Penyebab terjadinya kesalahan yang dilakukan siswa berkemampuan awal sedang dalam menyelesaikan soal-soal pecahan berdasarkan taksonomi bloom pada tahap mengevaluasi.

1) Siswa bingung dan tidak tahu cara penyelesaian soal.

2) Siswa tidak mengetahui rumus yang digunakan untuk menentukan persentase.

f. Penyebab terjadinya kesalahan yang dilakukan siswa berkemampuan awal sedang dalam menyelesaikan soal-soal pecahan berdasarkan taksonomi bloom pada tahap mencipta.

1) Siswa salah menggunakan operasi hitung pada pengurangan dan penjumlahan pecahan campuran.

2) Siswa tidak teliti dalam menyelesaikan soal-soal, sehingga SS1 tidak menyederhanakan hasil akhirnya.

3) Siswa bingung dalam memilih tanda operasi yang sesuai dalam meyelesaian soal.

Hendaknya sekolah senantiasa meningkatkan mutu dan kualitas pembelajaran disekolah dengan memberikan wacana untuk seluruh guru mengenai kesulitan-kesulitan siswa, terutama dari ranah kognitif siswa. Selain itu, hendaknya penelitian ini diajukan sebagai acuan untuk meneliti di tempat dan pada subjek lain dengan catatan kekurangankurangan yang ada dalam penelitian ini hendaknya direfleksikan untuk diperbaiki. 


\section{DAFTAR RUJUKAN}

Akib, Irwan. (2016). The Description Of Relatinship Between Mathematics Characteristic And Bugis Culture Values. Global journal of pure and applied mathematics.

Anderson Lorin. (2015). Kerangka Landasan untuk Pembelajaran, Pengajaran, dan Asesmen Revisi Taksonomi Pendidikan Bloom. Penerbit Pustaka pelajar. Yogyakarta.

Noraida Ariyunita. (2012). Analisis Kesalahan Dalam Menyelesaikan Soal Operasi Bilangan Pecahan Siswa Kelas VII SMP Negeri 2 Karanggede. Skripsi tidak Diterbitkan. Universitas Muhammadiyah Surakarta.

Syamuhibbin. (2010). Psikologi Pendidikan Dengan Pendekatan Baru. Bandung :PT Remaja Rosdakarya.

Sumarniati. (2012). Indikator Kesalahan Menurut Peraturan Dirjen Depdiknas Nomor $506 / \mathrm{c} / \mathrm{kep} / \mathrm{pp} / 2004$. 